\title{
Subsurface structure of St. Elmo submarine volcanic mound (Austin, Texas) and its volcanic conduits imaged using geophysical methods
}

\author{
Mustafa Saribudak ${ }^{*}$ \\ Environmental Geophysics Associates, Austin, Texas, USA.
}

\begin{abstract}
Geophysical survey techniques including electrical resistivity imaging and magnetics were utilized to study the late-Cretaceous submarine volcanic mound of St. Elmo railroad cut located in south Austin, TX. The St. Elmo site cut exposes a sequence of late Cretaceous volcaniclastic rocks in contact with carbonate rocks. Resistivity imaging results provided subsurface evidence that the St. Elmo submarine mound has high resistivity limestone blocks scattered randomly within the resistivity sections. These limestone blocks are interpreted to be erratic blocks of Austin Chalk, which were probably torn from the walls of the volcanic conduits (vents) and ejected. Magnetic anomalies correlate well with the resistivity anomalies, strengthening the interpretation of the resistivity data. Resistivity results from the residential site, not far from the St. Elmo volcanic mound, are interpreted as a conduit which is similar to the conduit anomalies observed on the St. Elmo railroad cut site.
\end{abstract}

\section{ÖzET}

Austin, Teksas'da St. Elmo caddesini kesen trenyolu civarinda bulunan Üst Kretase denizaltı volkanik höyük mostralarında jeofizik (özdirenç ve manyetik) yöntemler uygulanmistir. Bu St. Elmo mevkiisinde, volkanosedimenter kayaclar, genellikle tüff, yine Üst Kretase yaşli kirectaşlari ile kontakt halinde gözlenmiştir. İki boyutlu özdirenç kesitler, yüksek özdirençli kireçtaşi bloklarının düşük özdirençli volkanik höyük (tüff) icerisinde rastgele bir biçimde dağildiklarini göstermistir. Bu kireçtaşi blokları, büyük bir olasılikla, denizaltı volkanik yanardağ bacalarının püskürmesiyle baca duvarlarından koparilmiş ve tüffler içerisine atılmışlardır. Manyetik veriler de bu değerlendirmeyi desteklemektedir. St. Elmo höyüğüne yakın olan bir yerleşme birimi civarında (ev) yapılan özdirenç çalışmaları da benzeri sonuçlar vermiştir.

Keywords: Submarine volcanism; Volcanic vent; Resistivity; Magnetic; Austin Chalk; Texas

\section{InTRODUCTION}

Near-surface geophysical imaging is used in a wide range of volcanic settings to understand the internal structure of volcanic centers and the nature of volcanic deposits [e.g. Courtland et al. 2012; Barde-Cabusson et al. 2013; Di Giuseppe et al. 2017; Saribudak and Caran 2015; Saribudak 2016; Blaikie et al. 2014; Di Giuseppe et al. 2015; George et al. 2015; Marshall et al. 2015]. In this study, electrical resistivity imaging is used to resolve near-vent structures. Electrical imaging has a specific capability to resolve subsurface features of the buried volcanic deposits based on electrical resistivity contrasts in some volcanic deposits.

Such electrical resistivity contrasts occur in the Cretaceous strata of Austin Chalk of south-central Texas, where they contain electrically conductive (low resistivity) volcanic domes or mounds [Ormond 1984; Young et al. 1982]. These volcanic mounds, referred to locally

\footnotetext{
*Corresponding author: mbudak@pdq.net
}

as "serpentine plugs", are part of a period of distributed monogenetic volcanism [Valentine and Connor 2015] exposed in the Austin area and elsewhere in the Balcones Magmatic Province (BMP) [Ewing and Caran 1982; Griffin et al. 2005; Caran et al. 2012, and see Figure 1]. Within this province there are approximately 200 occurrences of igneous outcrops emplaced during the deposition of the Austin Chalk. These bodies consist of shallowly emplaced igneous structures associated with vents, and pyroclastic rocks and lavas erupted on the now-deeply eroded and sub-aerially exposed shallow Cretaceous seafloor. These outcrops tend to align along NE-SW regional faults and fractures of the Balcones faults of the Miocene age ( 20 Ma). Thus, this distributed volcanic field is of interest because it is among the youngest volcanism found in the south-central USA, is associated with a major tectonic feature that was active long after the cessation of volcanism, and provides an opportunity to study the geophysics of vents formed in a shallow marine environment. 

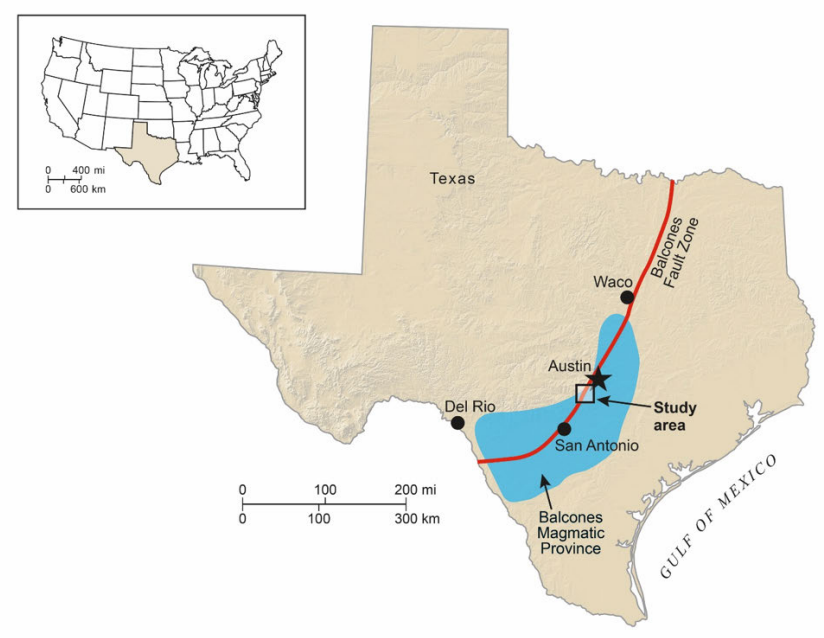

Figure 1: Maps showing the Balcones Magmatic Province and the Balcones Fault Zone, and the study area (modified after Saribudak [2016]). The Balcones Magmatic Province is defined by the surface extent of Cretaceous igneous rocks.

Previous geologic mapping and stratigraphy [Ewing and Caran 1982; Caran et al. 2012], have demonstrated that these tuff mounds have all the hallmarks of smallvolume submarine volcanic vents [Kano 1998; Kokelaar and Busby 1992; Mueller 2001; Schneider 2000], including shallow diatreme structures in which Austin Chalk is brecciated and reworked, tuff-ring structures, remobilized palagonitized tuff as gravity currents (submarine lahars), and intrusive features (dikes, small sills and conduits, as shown in Figure 2).

In this study, a volcano-sedimentary section was mapped at the St. Elmo railroad cut, which was previously identified as a submarine tuff mound [Moon 1942; Caran et al. 2012]. Both resistivity imaging and magnetic methods were used. The purpose of these geophysical surveys was to image the near-vent volcanic facies, especially their relationship to the Austin Chalk limestone [Young et al. 1982; Young and Woodruff 1985]. Geophysical data of submarine vents (conduits) is understandably sparse, so the St. Elmo site provides an excellent opportunity to study the vent structure in a now terrestrial setting.

In addition, three resistivity profiles were surveyed on eastern and western sides of a residence located about $360 \mathrm{~m}$ to the northwest of the St. Elmo site. The house was recently built on a small hilltop. We were hired to characterize the subsurface in terms of geology and geological structure to help assess the foundation's integrity. Resistivity results helped identify the volcanic rocks around the house, which improved our understanding of the vent system comprising St. Elmo volcanic mound.

\section{Previous geophysical work}

Since the volcanic mounds were first described in the Balcones Magmatic Province (BMP) by Udden and Bybe in 1916, significant hydrocarbon traps have been exploited in and around tuff mounds. Magnetic surveys over tuff mounds led directly to the discovery of similar oil fields, such as Hilbig, Jim Smith, Yoast, and Chapmon-Abbott fields in Texas [Collingwood 1930; Collingwood and Rettger 1926; Matthews 1986, and see Figure 3]. The integrated geophysical work on Pilot Knob, a volcanic vent in south Austin, included the application of magnetic and gravity methods, such as the study published by Romberg and Barnes in 1954 (Figure 3). In that seminal study, gravity and magnetic data were collected along several traverses with station spacing of $700 \mathrm{~m}$ in some sections and $1,400 \mathrm{~m}$ in others. The results revealed strong positive gravity and magnetic anomalies over the central basalt mass, and weaker anomalies caused by attendant flows and dikes. They also concluded that "serpentinized" pyroclastic rocks show weak, negative anomalies.

More recently, resistivity and magnetic data were collected along two profiles across Pilot Knob [Saribudak and Caran 2015], which is located about $10 \mathrm{~km}$ to the southeast of the current study area (Figure 3). Both the resistivity and magnetic data together indicate significant anomalies, which were interpreted to be due to volcanic features: a conduit, a dike and a crater. They also indicate the large tuff mound is cut by faults. More geophysical results (2D and 3D resistivity and magnetics) over the known outcrops of tuff and lava at the Williamson Creek site revealed a volcanic vent [Saribudak 2016]. Results of these geophysical studies [Saribudak and Caran 2015; Saribudak 2016], for the first time, revealed the presence of volcanic features that included vents, dikes and craters. This study is the extension of those previous studies, with particular emphasis on the structures of tuff mounds.

\section{Geological BACKGROUND}

The Austin Chalk Group lies within the Balcones Fault Zone, and outcrops in the Austin area. This unit comprises all of the surface geology, other than volcanic rocks. Young and Woodruff [1985] categorized the Austin Chalk Group into seven formations, which are identified in ascending order as: Atco, Vinson, Jonah, Dessau, Burditt, Pflugerville and Sprinkle (Table 1).

The Late Cretaceous volcanic rocks of the Austin area are part of a larger belt of volcanic and intrusive bodies that stretches over $400 \mathrm{~km}$ in a wide arc from the southwest to northeast in the state of Texas. Within this belt, igneous rocks were either erupted or intruded into a shallow epicontinental sea during deposition of the Austin Chalk. Thus, exposure of volcanic rocks in the Austin area and elsewhere in the BMP results from the interplay between submarine volcanic eruption and 


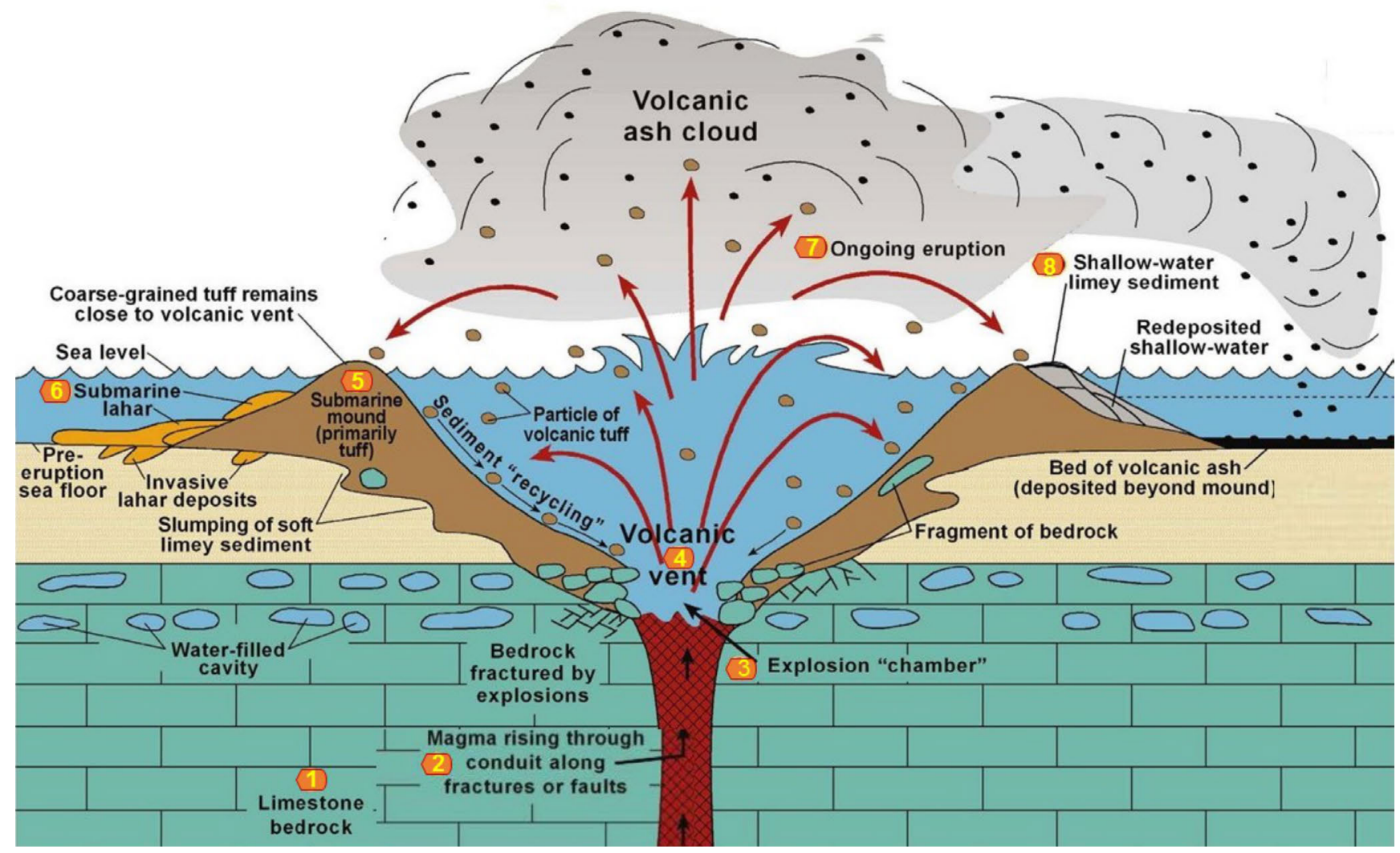

Figure 2: A schematic model of an erupting BMP submarine volcano and its near-vent architecture (modified after Caran et al. [2012]).

erosive sedimentary processes associated with submarine tuff complexes during the Upper Cretaceous time [Ewing and Caran 1982; Griffin et al. 2005].

In the railroad cut below St. Elmo road, palagonitized tuff outcrops are believed to have erupted from a nearby volcanic edifice [Caran et al. 2012, Figure 4]. The majority of the volcanic outcrop consists of pyroclas-

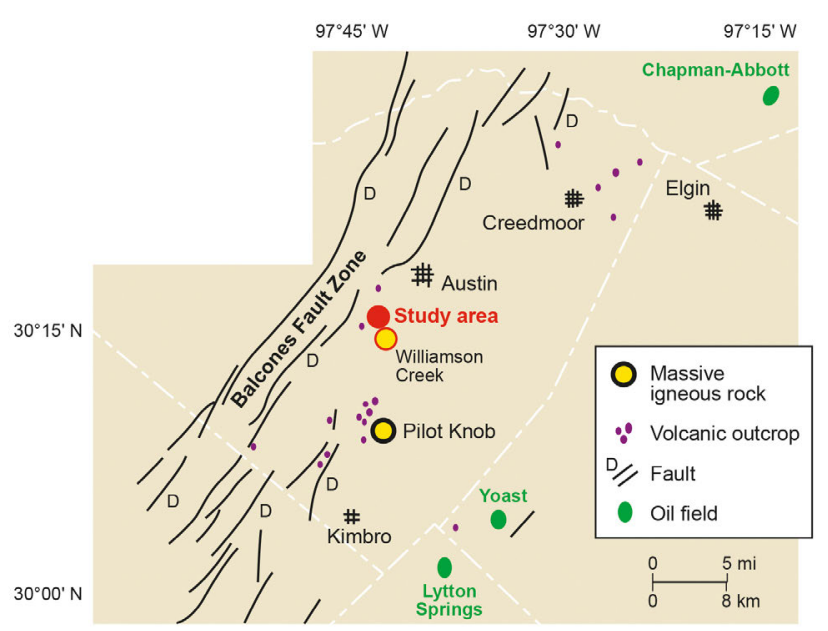

Figure 3: Map showing the current study area, Williamson Creek and Pilot Knob sites, and volcanic oil fields (modified from Saribudak and Caran [2015]). tic deposits, including brown lapilli tuff comprised of poorly sorted tephra, some layers of altered ash and limestone clasts [Caran et al. 2012]. Clasts of limestone are present at all levels in the tuff, and they range in size from around 1 to $25 \mathrm{~cm}$. The lapilli tuff at this location is interpreted to result from an eruption-fed density current on the basis of the presence of low angle cross-bedding, and intercalation of ash layers [Shelby 1934; Moon 1942; Caran et al. 2012]. The limestone clasts indicate near-vent deposition and sufficient explosive energy to erode the conduit wall.

Thus the depositional environment of the St. Elmo railroad cut area was geologically interpreted to be the central part of a tuff mound. Several layers of interlayered ash and tephra deposits with limestone clasts and lapilli tuff sections observed within the tuff mound represent an eruptive cycle of a volcano near the tuff mound [Caran et al. 2012].

A detailed geologic map of St. Elmo Bridge and surrounding area was published first by Young et al. [1982], and is redrawn in Figure 5. The geological map shows St. Elmo railroad cut and the residential site on the map with letters of $A$ and $B$, respectively.

A thick sequence of tuff $(20 \mathrm{~m})$ exposed around the South Austin Hospital during its construction is shown on the map. The site falls into the Balcones Fault Zone (BFZ), and there is a significant fault between the St. Elmo site and the residential site, which are indicated 

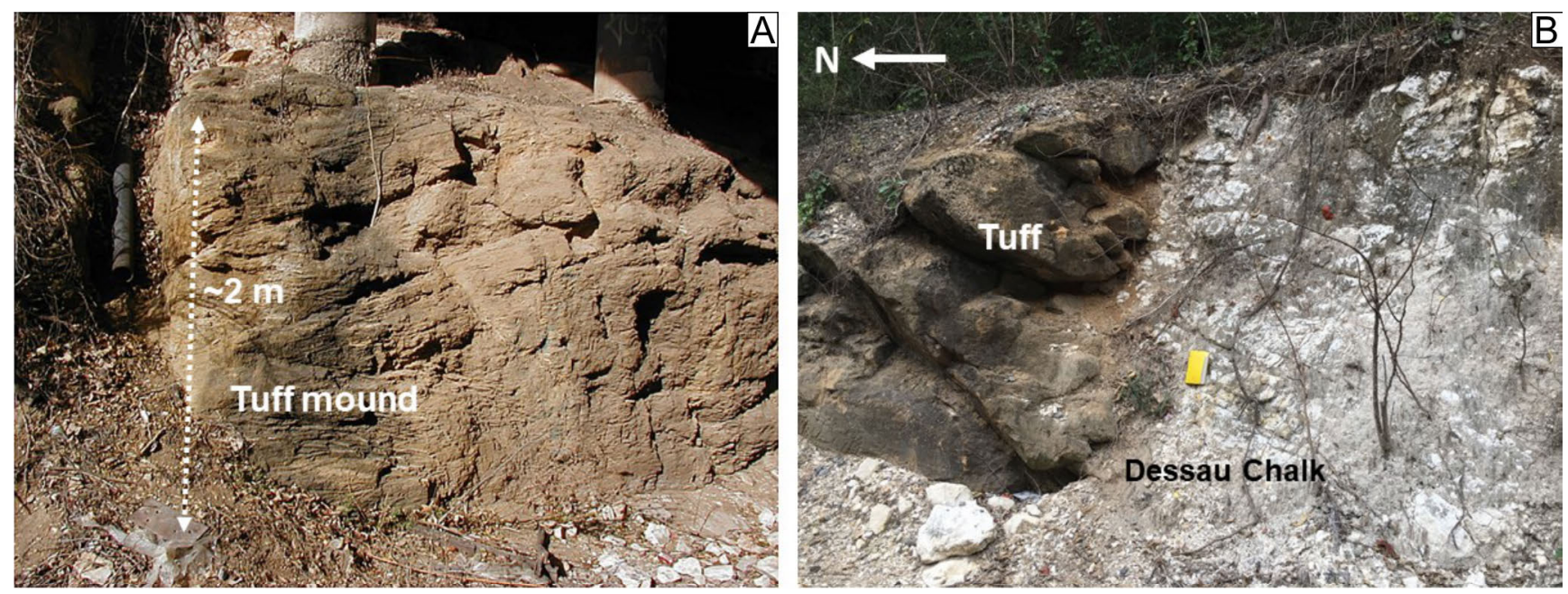

Figure 4: Tuff mound outcrop beneath the bridge [A] and the contact between Austin Chalk and tuff units [B] on the west and east faces of the St. Elmo railroad cut, respectively.

on Figure 5 as $\mathbf{A}$ and $\mathbf{B}$, respectively. The Williamson Creek site, where similar geophysical work was also undertaken a few years ago, is marked by $\mathbf{C}$ [Saribudak 2016].

\section{Geophysical Surveying Methods}

\subsection{Resistivity method}

The electrical resistivity method inolves imaging the bulk electrical resistivity distribution of the subsurface in two, three, or four dimensions (the three dimensions of space plus time when monitoring is performed) from the meter to hundreds of meter scale depending on the electrode spacing [Hermans et al. 2014]. Resistivity has been well documented in the geophysical literature [Loke 2000; Dahlin and Loke 1998; Griffiths and Barker 1993; Bruno et al. 2007; Saribudak 2016]. Resistivity values $(\Omega \mathrm{m})$ measured by the method are highly affected by several variables, including the presence of water or moisture, the amount and distribution of pore space in the material, and temperature [Rucker and Glaser 2015]. In this study, the Advanced Geosciences, Inc. (AGI) SuperSting R1 and R8 resistivity meters were used with a dipole-dipole electrode array. Compared to other arrays, this array is more sensitive to horizontal variations in the subsurface and, when the data are inverted, provides a $2 \mathrm{D}$ resistivity model that can be interpreted in terms of near-surface geology and geological structure.

A contact resistance test was performed before data collection. Contact resistance measures the resistance to current flow at electrodes caused by imperfect electrical contact with the earth. Poor data quality or anomalous data can result from high or highly variable electrode contact resistance along a profile. To decrease the effect of contact resistance along each profile a saltwater solution was added to each electrode before the con- tact resistance test was performed. Typical contact resistance for profiles varied between 100 and $250 \Omega$. Seven resistivity profiles were surveyed in the study area, on and off, between the years of 2013 and 2019.

A $2 \mathrm{D}$ inversion of the resistivity imaging profile was obtained using AGI's 2D EarthImager commercial software [EarthImager ${ }^{\mathrm{TM}}$ 2014]. A topographic correction was applied to the resistivity profile where needed. The final output, which is the inverted section, represents the result of an iterative process that tends to minimize the difference between measured and calculated resistivity values. The Root Mean Squared (RMS) error gives a measure of this difference. In this study, RMS values of six inverted resistivity sections range between 3 and 8 , and the seventh profile has a RMS value of 11 . These are acceptable results, being of the same magnitude of the values that characterize inversion of data collected in volcanic environments [Bruno et al. 2007; Loke 2000; Xia et al. 2010; Di Giuseppe et al. 2017; Saribudak and Caran 2015; Saribudak 2016].

\subsection{Magnetic method}

The magnetometer measures magnetic field. The unit of measurement for the magnetometer is the nanoTesla (nT). In this study, a Geometrics G-858 Cesium magnetometer was employed in the collection of the data along profiles P5, P6, and P7 which are located on the western and eastern parts of the site, respectively (Figure 6). The collection rate of the magnetic data was $10 \mathrm{~Hz}$, which corresponds to better than one data point every $0.3 \mathrm{~m}$ along the magnetic profiles. A base station was established in the vicinity of the site to record the daily variations of Earth's external magnetic field. The magnetic survey time was less than 30 minutes, and there were no significant diurnal variations. For this reason, a diurnal correction was not applied to the magnetic data. A low-pass filter was applied to the magnetic 


\section{Quaternary}

Qal

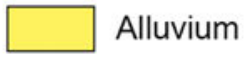

$\mathrm{Qg}$

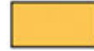

Gravel

\section{Cretaceous}

Austin Group

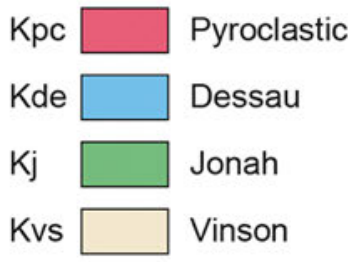

A St. Elmo railroad cut site

B Residential site

C Williamson Creek site (Saribudak, 2016)

ك Location of S. Austin hospital

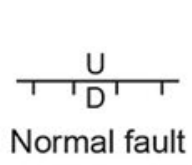

Normal fault

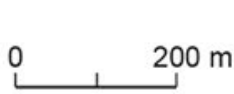

Dow

个 Austin
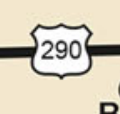

B

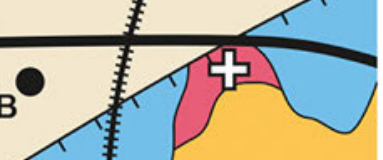

\section{Qg}

Kde
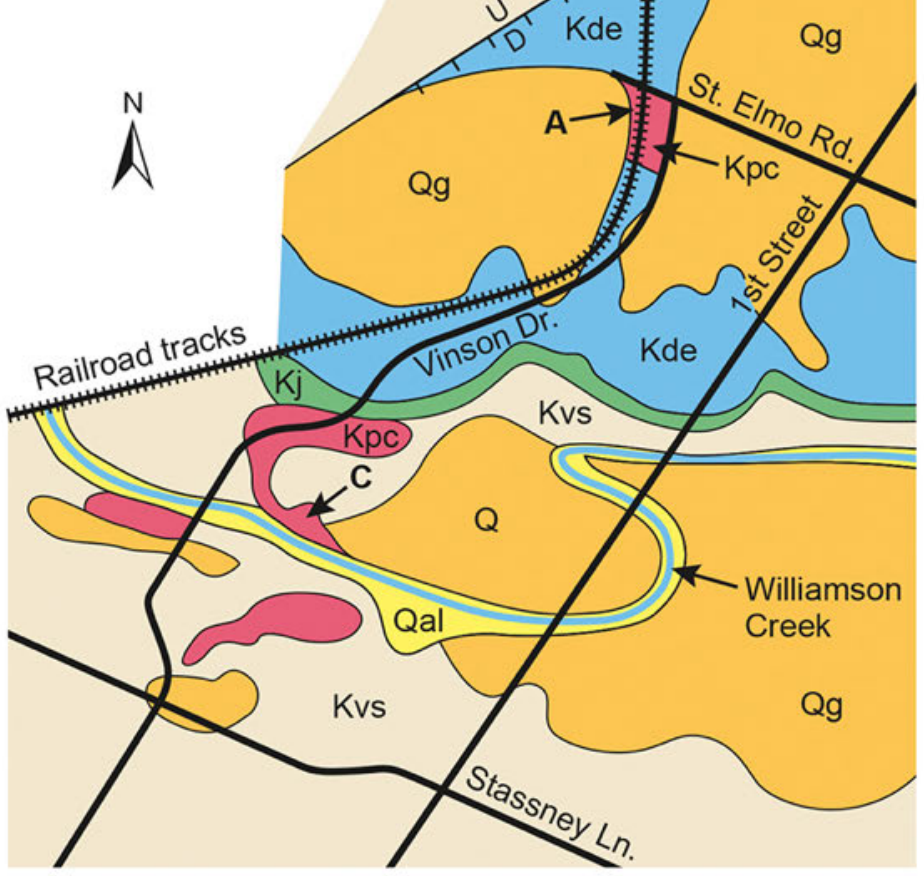

Figure 5: A geological map of the study and surrounding areas. The map is based on the original map published by Young et al. [1982]. Note that a significant fault of the BFZ is crossing south of the residential site (B).

data to reduce noise.

The site presented challenging conditions for the magnetometer surveys due to the presence of some fences, roads with busy traffic, the bridge, and the railroad track. However, the locations of magnetic profiles were a minimum distance of $13 \mathrm{~m}$ from the railroad tracks, which did not appear to have any significant effect on the magnetic readings. The presence of the bridge did affect the readings, and these anomalous data were removed from the dataset along profile P5. The locations of profiles P6 and P7 were restricted to south of the bridge only. A strongly enforced ferrous property fence further to the north on the eastern part of the railroad track made data collection there impossible. Thus we stayed in the southern section, and the only challenge to the quality of the magnetic data being collected there was the road traffic. To avoid potential interference, the magnetometer was paused approximately $30 \mathrm{~m}$ before any car drove by. In addition, we collected the magne- tic data in two directions (north to south and south to north); both datasets were comparable, indicating that the effect of ambient noise was not significant.

\section{Geophysical Surveying Results}

\subsection{St. Elmo}

Four resistivity profiles (P1, P2, P3, and P4) and three magnetic profiles (P5, P6, and P7) were surveyed at the site. Locations of the geophysical profiles are shown on a site map (Figure 6A) and on a detailed, schematic geological map of the site, which shows the locations of late Cretaceous volcaniclastic and carbonate rocks of Austin Group (Dessau Chalk) where they are in a geological contact (Figure 6B).

The geological contact is interpreted as fault between the volcaniclastic rocks and the Austin chalk by Caran 


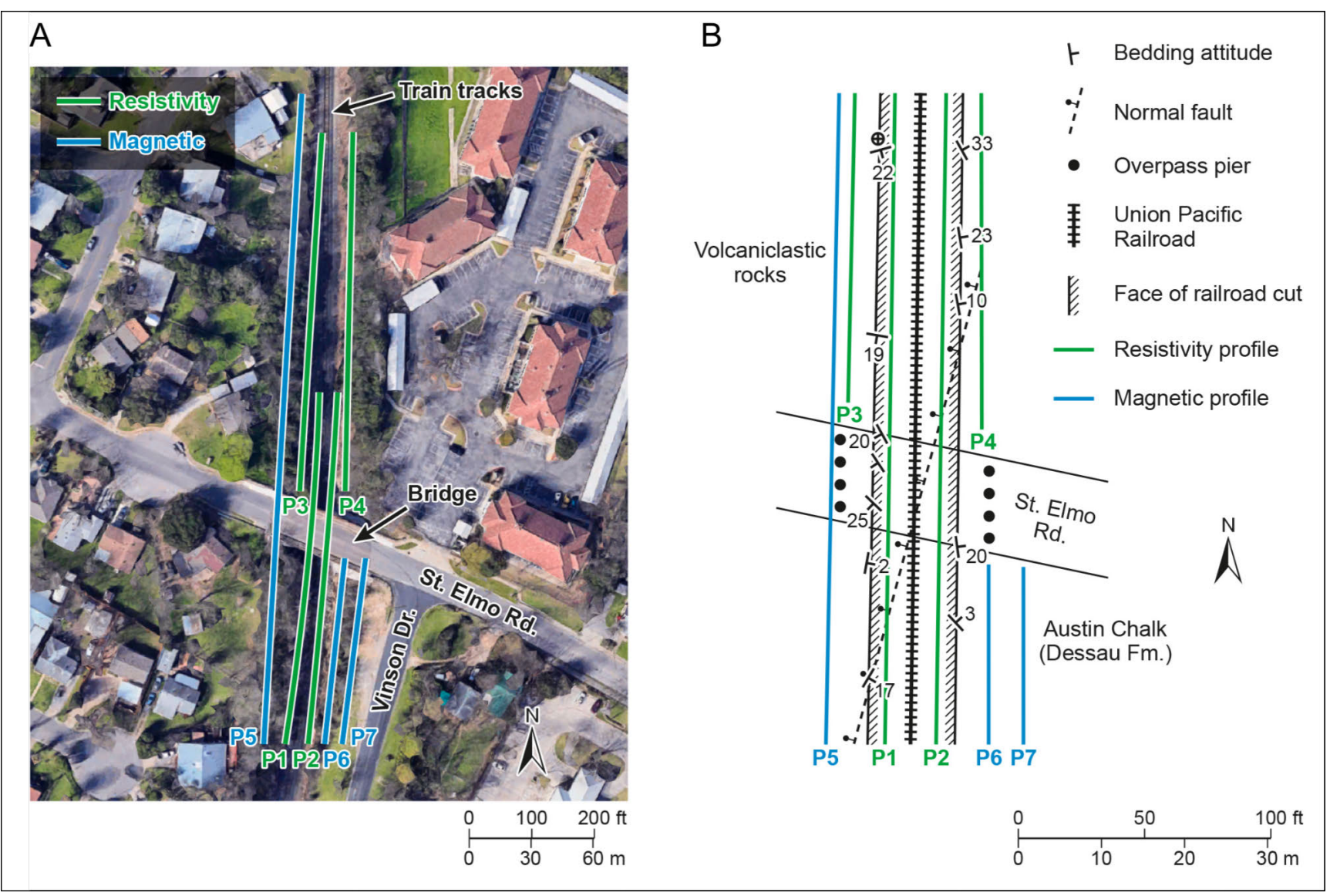

Figure 6: Locations of geophysical profiles on a site map [A] and on a schematic geological map of the St. Elmo site [B]. The geological map was published in Caran et al. [2012]. Note that all profiles (except P6 and P7) extend in the southern and northern directions beyond the map boundaries.

et al. [2012] (see Figure 6B). The azimuth of this fault is considerably more northerly than that of most Balcones faults in this area, and the westerly dip of the fault is opposite to the faults of the Balcones system [Caran et al. 2012].

Two resistivity profiles (P1 and P2) were established to the immediate East and West of the railroad tracks beneath St. Elmo Bridge. The spacing between the profiles was $8 \mathrm{~m}$, and the electrode spacing was held at 6 $\mathrm{m}$ on both profiles. A train runs every few hours, and extra caution was taken while working at this locality. For this reason, contact resistance through the rails was not measurable. Because the trains always sound their horns, we were able to shut the resistivity meter long before the train arrived at our survey location in order to avoid anomalous electrical measurements. We restarted the survey after the train disappeared from the view.

The third and fourth resistivity profiles (P3 and P4) were located in the northern section of St. Elmo Bridge above the railroad track in the western and eastern parts of the site, respectively. The electrode spacing was held at $\sim 2.5 \mathrm{~m}$ on both surveys. Note that both profiles are located higher $(2.5 \mathrm{~m})$ and farther $(8 \mathrm{~m})$ from the railroad tracks (see Figure 6A for location).

\subsubsection{St. Elmo Resistivity Profiles}

Figure 7 shows the resistivity data collected along the West (P1) and East (P2) of St. Elmo railroad track, respectively. The two profiles are separated by about 8 meters. Locations of the contact between the boundaries of Austin Chalk and pyroclastic rocks, as well as the first and last piers of the bridge of St. Elmo Road are also shown on resistivity profiles as reference points.

It has been previously shown that railroad tracks have an effect on the apparent resistivity data [Wilkinson 2006]. Apparent resistivity measurements made in proximity to a rail track with any type array configuration are likely to be reduced by preferential current channeling through the conductive rails, with greater distortion of the data at larger depths of investigation. The effect is minimized, however, for the dipole-dipole configuration, which is therefore recommended for resistivity surveys undertaken parallel to conductive rails [Wilkinson 2006]. Despite the presence of railroad tracks, the quality of the resistivity data on both profiles of P1 and P2, based on their RMS values, is good to excellent.

Lower and upper resistivity values of both profiles are fixed similarly so that a correlation between the 


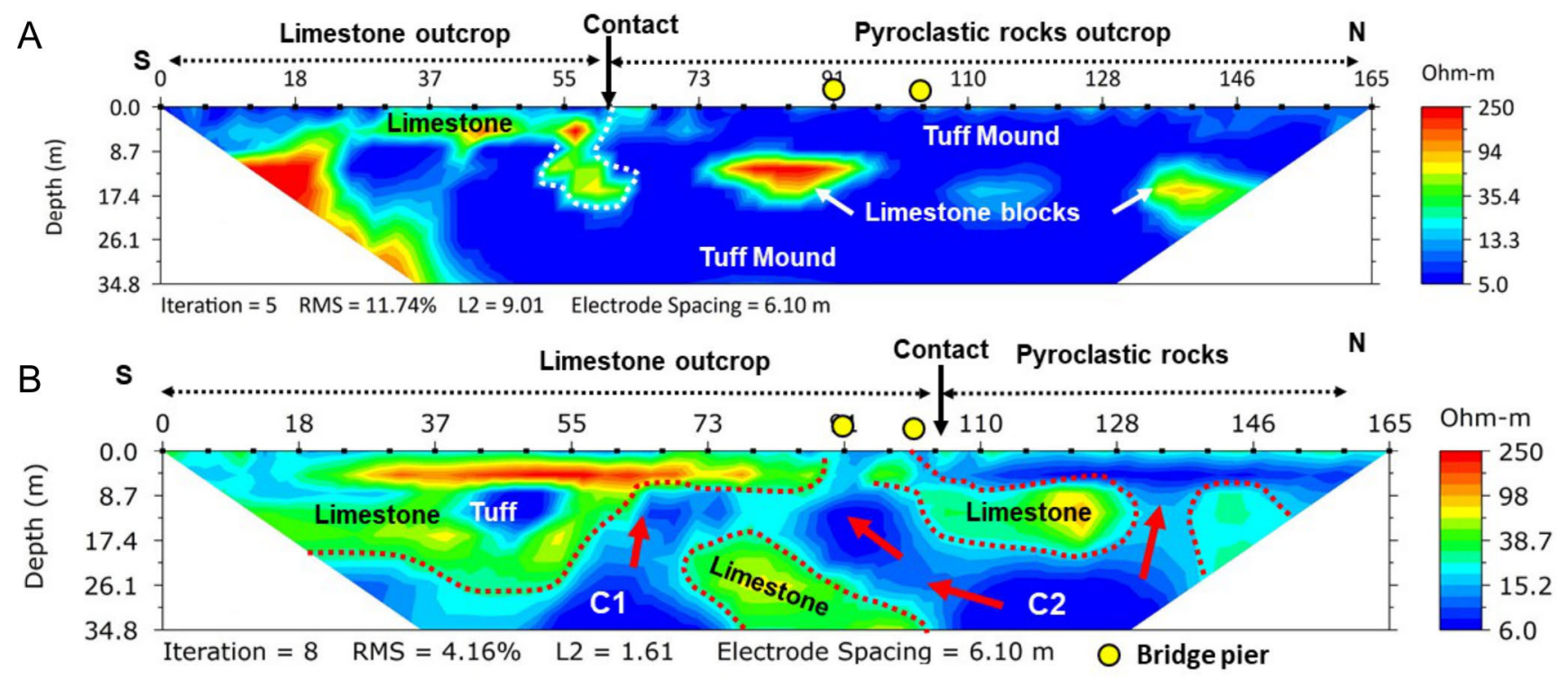

Figure 7: Resistivity profiles of P1 and P2 obtained from the western [A] and eastern [B] side of St. Elmo railroad track, respectively (see Figure 6 for locations). Boundaries of exposed pyroclastic and limestone outcrops, the contact, and most southern and northernmost bridge piers are shown for reference purposes.

two can be made correctly. Low resistivity values $(5$ to $15 \Omega \mathrm{m}$ ), which are shown in blue on Figure 7 and correspond to the pyroclastic outcrops in the field, cover the majority of the resistivity profile $\mathrm{P} 1$. There are high resistivity blocks within the pyroclastic rocks to the north of the geological contact. The contact, which is interpreted to be a fault by Caran et al. [2012], separates low resistivity rocks (pyroclastic or tuff) in the North from the moderate resistivity rocks (limestone) in the south superficially. However, this separation is only valid at the surface because an irregular limestone block of significant size extends in the vicinity of the contact and terminates against tuff (see white-dashed line in Figure 7A). In return, tuff underlying the limestone outcrop continue across the contact and ascend, with an irregular geometry (Figure 7A). Overall, the resistivity data along P1 indicates a tuff mound, which is shown with the blue (low resistivity) color along the profile, which extends as deep as $\sim 35 \mathrm{~m}$.

The resistivity data along profile $\mathrm{P} 2$, which is located $8 \mathrm{~m}$ to the east of profile P1, is provided in Figure 7B. Profile P2 indicates more chaotic distribution of low, medium and high resistivity values. The geological contact appears to separate pyroclastic rocks (low resistivity) in the north from the carbonate rocks (medium to high resistivity), but it is again only valid at shallow depths. Large, randomly distributed limestone blocks are located within the resistivity section. These limestone blocks are probably erratic blocks of Austin Chalk (Dessau Formation) which were torn from the walls of the conduit during eruption and reworked in the nearsurface diatreme. The resistivity data on profile P2 indicate two conduit-like anomalies continuous at depth, which are labeled C1 and C2 (see Figure 7B).

The resistivity data on profiles $\mathrm{P} 3$ and $\mathrm{P} 4$, which were surveyed on the West and East sides of the railroad track, respectively, are shown in Figure 8. The data reflect topographic correction, and the maximum depth of investigation is about $35 \mathrm{~m}$. Low resistivity values ( 3 to $20 \Omega \mathrm{m}$ ) underlie the entire section along profile P3, which in turn, are overlain by an exposed, thin terrace deposit (Figure 8A). The resistivity data indicate mostly tuff overlain by the terrace deposit layer, and do not indicate any presence of limestone blocks.

In contrast to profile P3, resistivity data on profile P4 display a chaotic distribution of limestone and tuff units as shown in Figure 8B. The resistivity data indicate a conduit-like anomaly (C3) ascending and cutting through Austin limestone blocks. It should also be noted that profile $\mathrm{P} 4$ crosses the geological contact between Austin limestone and tuff at station $133 \mathrm{~m}$ (see Figure 8B). The geological layers underlying the terrace deposit, which has a thickness of a few meters, do not show any displacement at the contact. This observation indicates that the contact between tuff and limestone units is not due to a fault.

We must point out that the resistivity values obtained from four profiles along the railroad track show similar ranges of resistivity values with the Williamson Creek vent, where there was no anthropogenic effect of any kind [Saribudak 2016]. This observation suggests that the resistivity values obtained at this site have not been significantly compromised by the railroad tracks. 


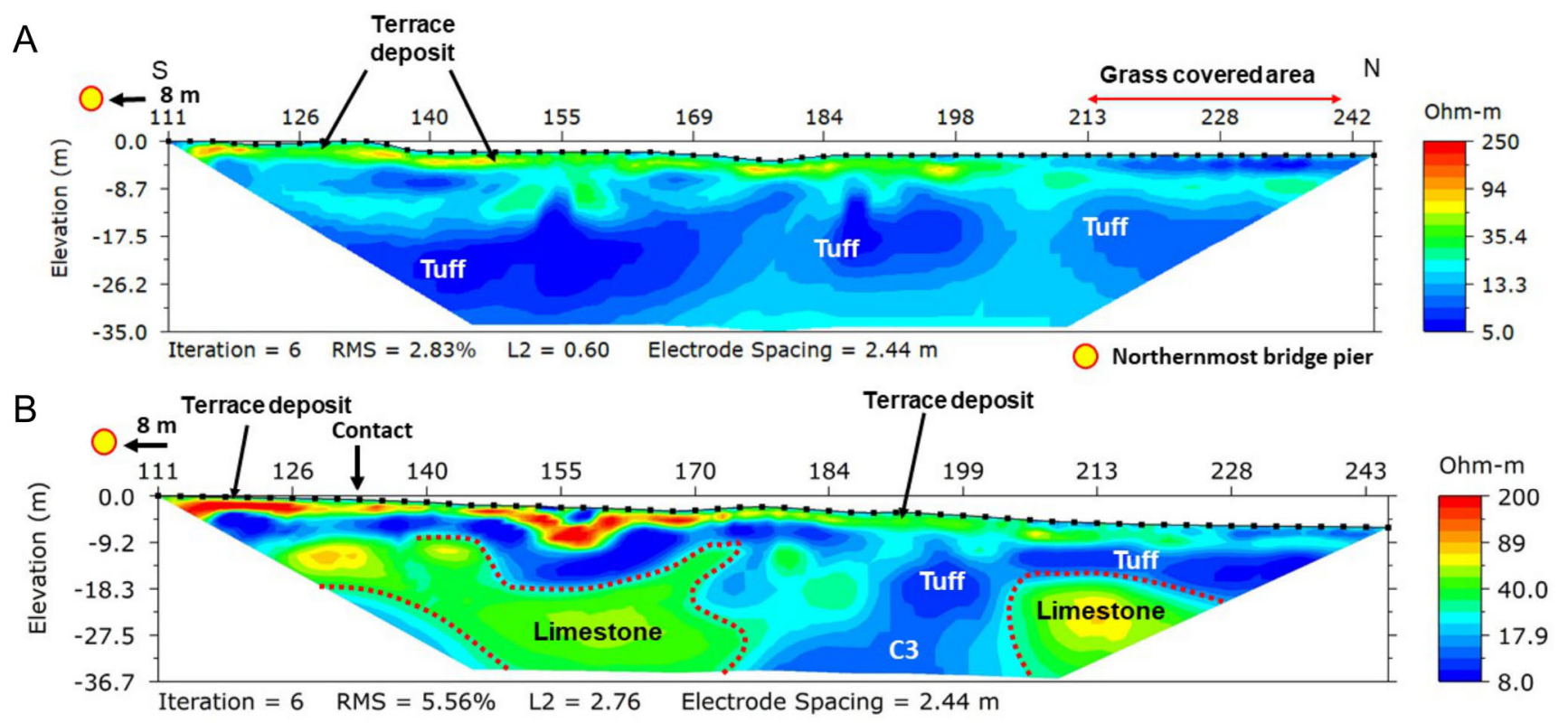

Figure 8: Resistivity data obtained along profiles P3 [A] and P4 [B] on the west and east side of the railroad track, respectively. Note that resistivity profiles are separated by $25 \mathrm{~m}$, yet they offer different geoelectric sections from each other.

\subsubsection{St. Elmo Magnetic Profiles}

The observed magnetic data of profile P5 contains very short-wavelength noise associated with material deposited at the surface by human activity (trash, pipes, etc.). The magnetic values vary between 46,300 and $47,800 \mathrm{nT}$. The average background magnetic value is about 47,400 nT in the south Austin area. The highest magnetic values occur near the St. Elmo Bridge, which is probably due to the metallic sources in and around the bridge (Figure 9). We applied a 4-meter low-pass filter to the observed data presented in Figure 9. Due to the high magnetic noise originating from the bridge, that portion of the survey was removed from the data. The remaining magnetic data indicate two significant anomalies: 1) A magnetic high starting at the contact between the chalk and volcanic rocks near the $60-\mathrm{m}$ station; 2) A magnetic low anomaly starting at about the 174-m station within the volcanic rocks. These two anomalies were present in the raw data on both survey directions from both north to south and south to north.

Two magnetic profiles (P6 and P7) were collected on the east terrace of the railroad track. Both magnetic data sets indicate a magnetic high anomaly between the stations at $53 \mathrm{~m}$ and $62 \mathrm{~m}$, and are annotated as $A$ and B (see Figure 10).

Locations of magnetic high anomalies (A and $\mathbf{B})$ observed on profiles P6 and P7 align well with the location of the volcanic conduit (C1) anomaly interpreted on the resistivity profile P2 (see Figure 7B).

\subsection{Residential Results}

The residential site is located $350 \mathrm{~m}$ to the northwest of the St Elmo railroad cut, where we conducted two resistivity surveys (P8 and $\mathrm{P} 9$ ) along the western and eastern part of the house, respectively (Figure 11). We conducted another resistivity profile (P10) $30 \mathrm{~m}$ to the south of profile P9. We were not able to conduct magnetic surveys along resistivity profiles due to ferrous cultural sources, such as the house itself, the concrete driveway around the house, air-conditioning units, and cars.

The house displayed significant cracks on the walls, windows and doors near the cistern (old water well). An eyewitness account of the cistern indicated that the water well might have been 4 to $6 \mathrm{~m}$ deep and had been backfilled, but the backfill exhibited continuous settlement which motivated the owner of the house to pursue geophysical testing.

The objective of the resistivity study then was to characterize the subsurface in terms of geological layers and structure, and help determine the cause of the deformation of the house.

\subsubsection{Residential Resistivity Profiles}

The resistivity data obtained along profiles $\mathrm{P} 8$ and $\mathrm{P} 9$ are provided in Figure 12. The spacing between both profiles was about $\sim 20 \mathrm{~m}$. Locations of the cistern and corners of the house are also provided for reference purposes. The resistivity data indicate a significant lowresistivity anomaly between the stations at $24 \mathrm{~m}$ and $38 \mathrm{~m}$ on both profiles. This anomaly has sharp contacts 


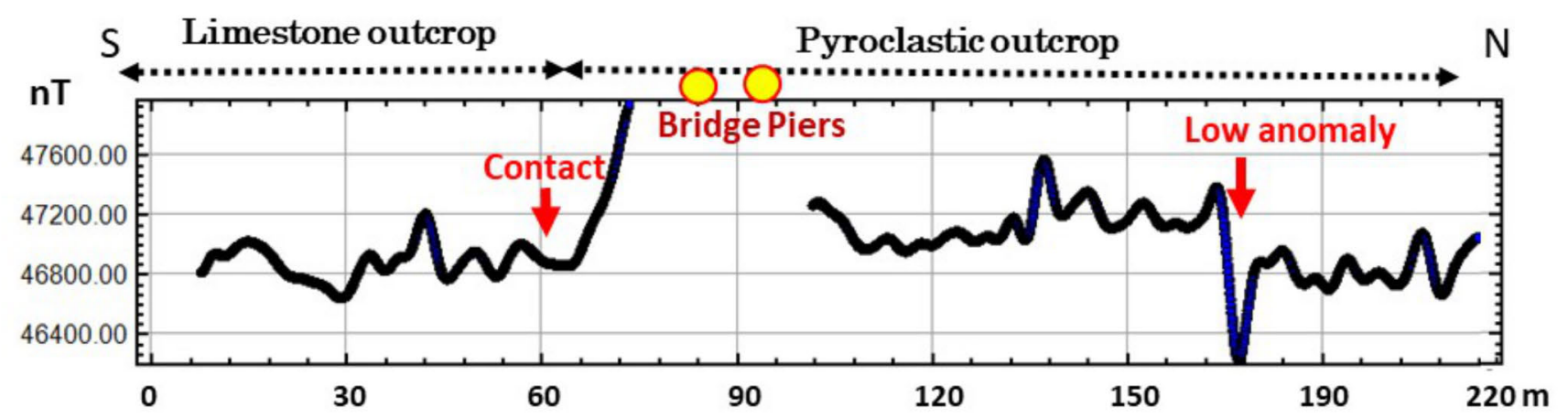

Figure 9: Magnetic data along profile P5. Note the significant variation of magnetic values across the contact between limestone and pyroclastic deposits, and a low magnetic anomaly location at station $185 \mathrm{~m}$.

A

nT
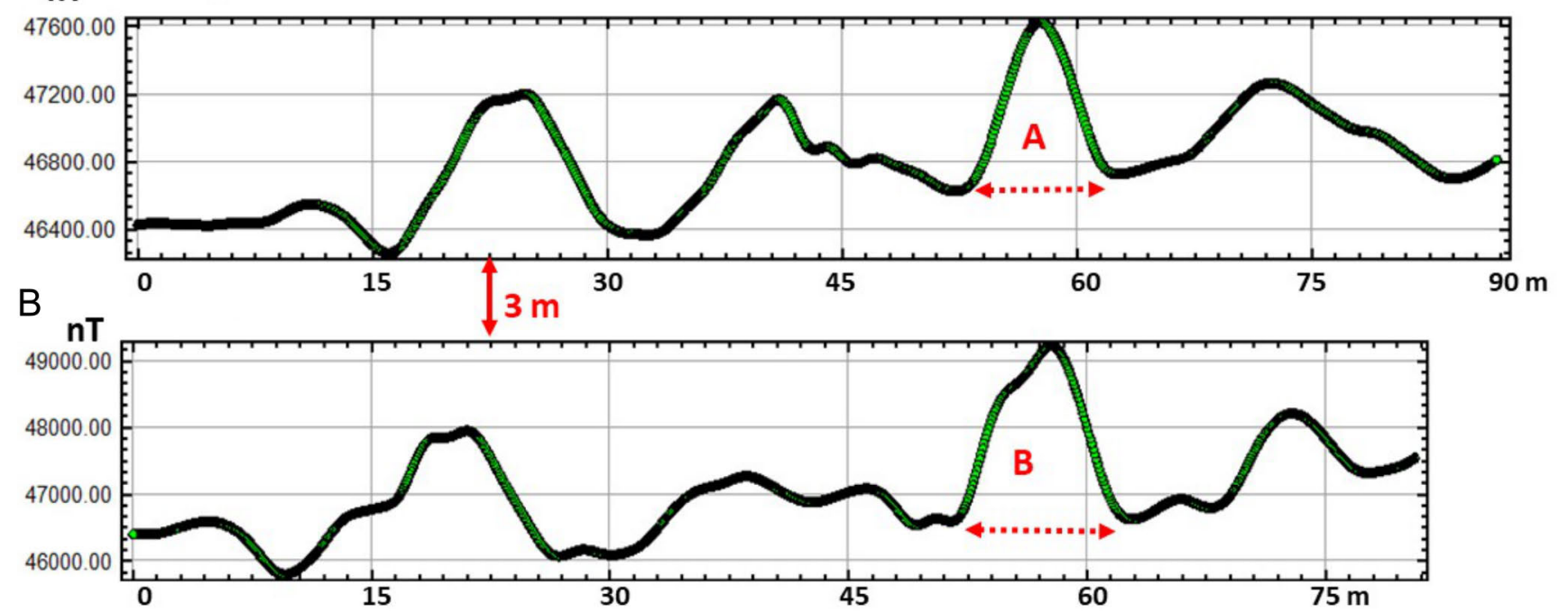

Figure 10: Magnetic data on profiles P6 [A] and P7 [B]. Note that the two data sets are quite correlative and indicate a high magnetic anomaly $(\mathbf{A}$ and $\mathbf{B})$ are at about the same station.

on both sides at the depth of the Austin Chalk, which are shown with higher resistivity values of green, yellow and red colors. Thus the source of the low resistivity anomaly in the center of the profiles could be due to a volcanic conduit, and is marked as $\mathrm{C} 4$.

The geometry and dimension of the conduit anomaly $\mathrm{C} 4$ are similar and comparable to the conduit-like anomalies of $\mathrm{C} 1, \mathrm{C} 2$ and $\mathrm{C} 3$ observed on resistivity profiles $\mathrm{P} 1, \mathrm{P} 2$ and $\mathrm{P} 4$.

The resistivity data along profile $\mathrm{P} 10$ is provided in Figure 13 . We surveyed this resistivity profile $30 \mathrm{~m}$ to the south of profile P9. The purpose was an attempt to delineate the horizontal extension of the conduit-like anomaly (C4) observed on profile P9.

The resistivity data do not indicate any conduit anomaly as observed on both profiles of P8 and P9. Instead, low resistivity values, between 6 and $20 \Omega \mathrm{m}$, are dominant, and layered along the entire length of the profile. Relatively high resistivity values, between 20 and
$200 \Omega \mathrm{m}$, are only observed in the southwest corner of the profile.

Resistivity profiles and borehole locations of the residential site are shown using Google Maps ${ }^{\mathrm{TM}}$ and are shown in Figure 14.

As part of the foundation evaluation, five soil borings were taken around the perimeter of the foundation of the house, and results were provided in two interim reports by two foundation companies [Read 2017; Capital Geotechnical Services, PLLC 2017]. The borehole data and their subsurface interpretations were taken and modified from these reports and are provided here. The depth of these boreholes varied between 4 and $8 \mathrm{~m}$. A picture of borehole operation at the study area is provided in Figure 15.

Boreholes B-1 and B-2 are located within the low resistivity anomaly that was interpreted to be due to a volcanic conduit. The contact between Austin Chalk and tuff deposit start with a "suspected ash layer" at 


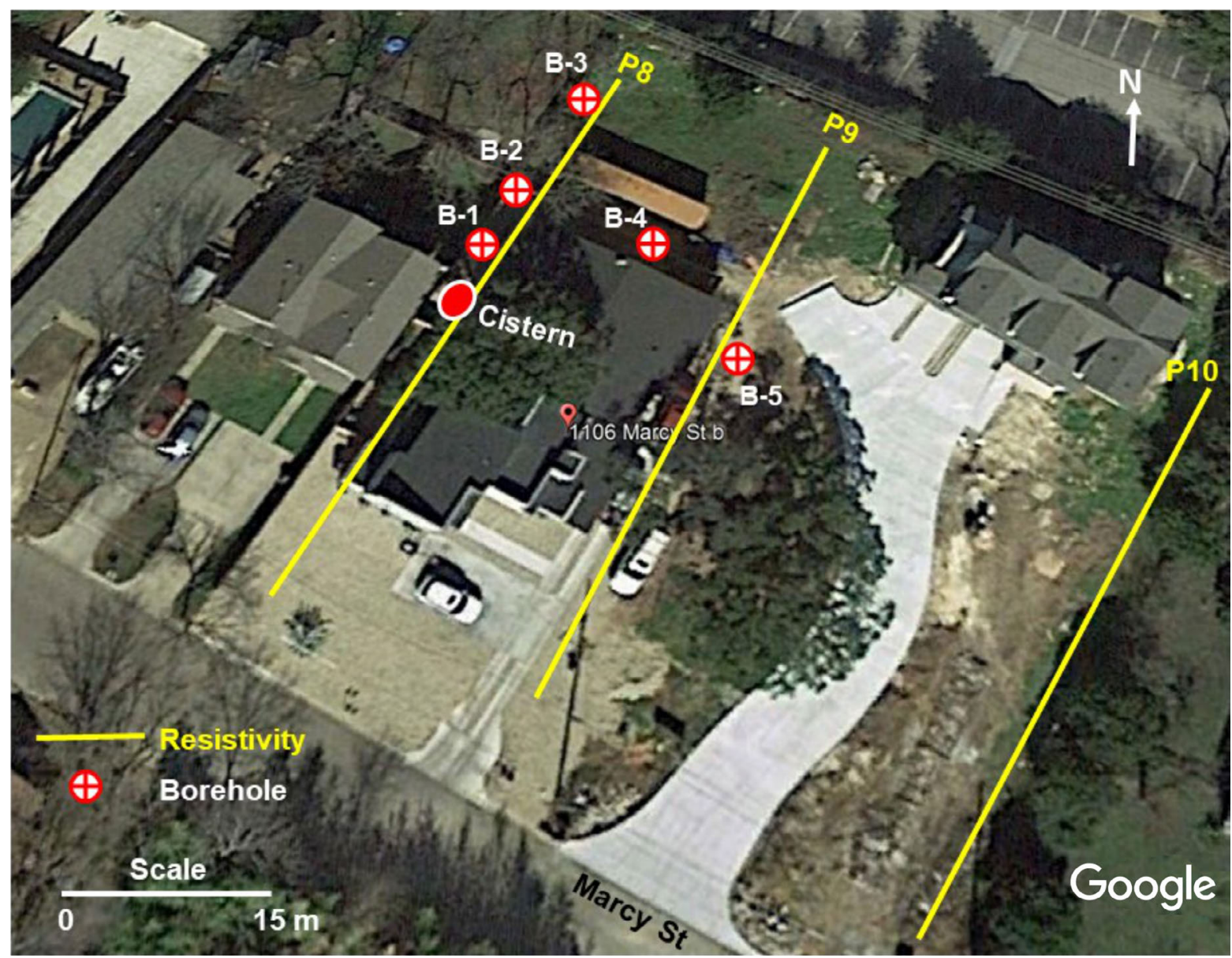

Figure 11: Site map of the house showing locations of resistivity profiles (P8 through P10) and the recently uncovered cistern along profile P8. Five borings (B-1 through B-5) were obtained during the investigation of the foundation of the residence. Note that the length of the profiles were restricted by a road and a fence in the southern and northern sections of the study area, respectively. O2019 Google LLC, used with permission. Google and the Google logo are registered trademarks of Google LLC.
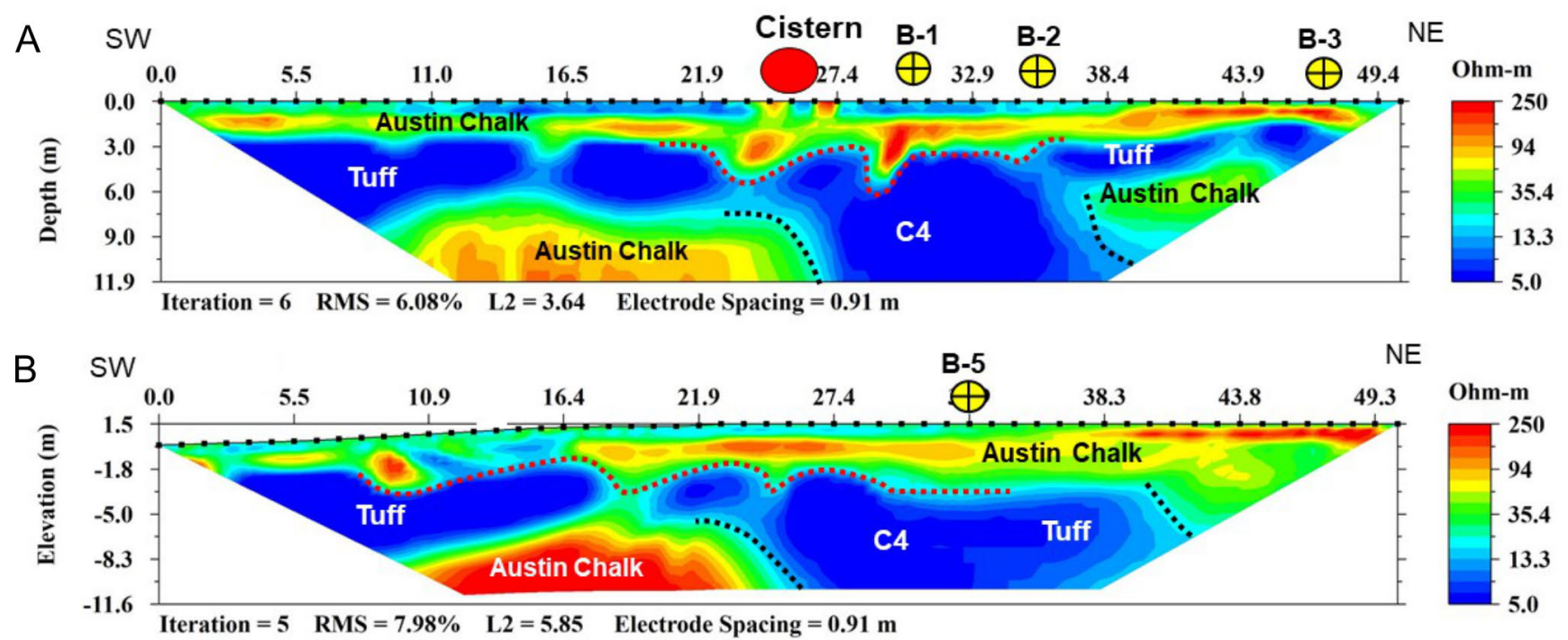

Figure 12: Resistivity data along profiles P8 $[\mathrm{A}]$ and P9 $[\mathrm{B}]$ at the residential site. Dashed red lines on the resistivity profiles indicate the top of tuff units beneath the Austin Chalk. Dashed black lines indicate the vertical contact on each side of the low resistivity anomaly caused by tuff. 


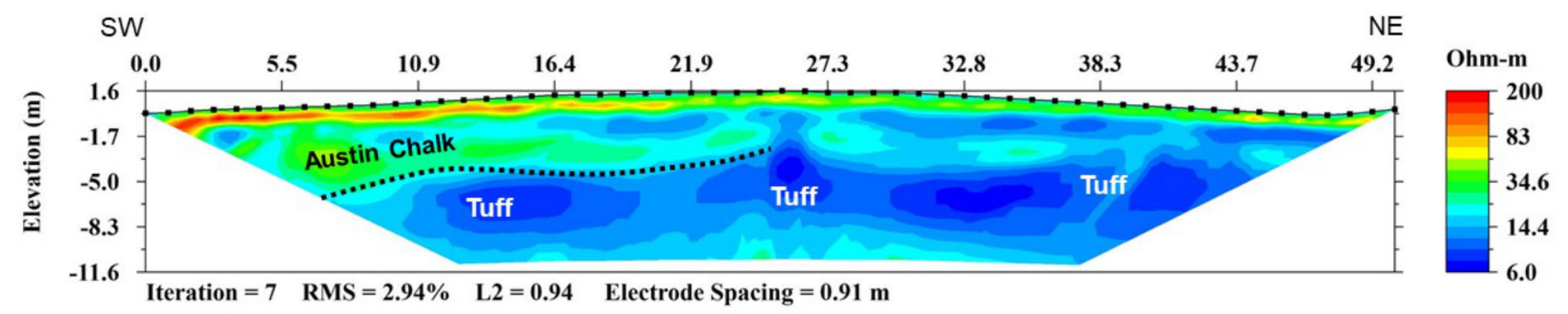

Figure 13: Resistivity data along profile P10. Note that resistivity layers are horizontal and a conduit-like intrusive anomaly observed on profiles P8 and P9 is absent from this profile.

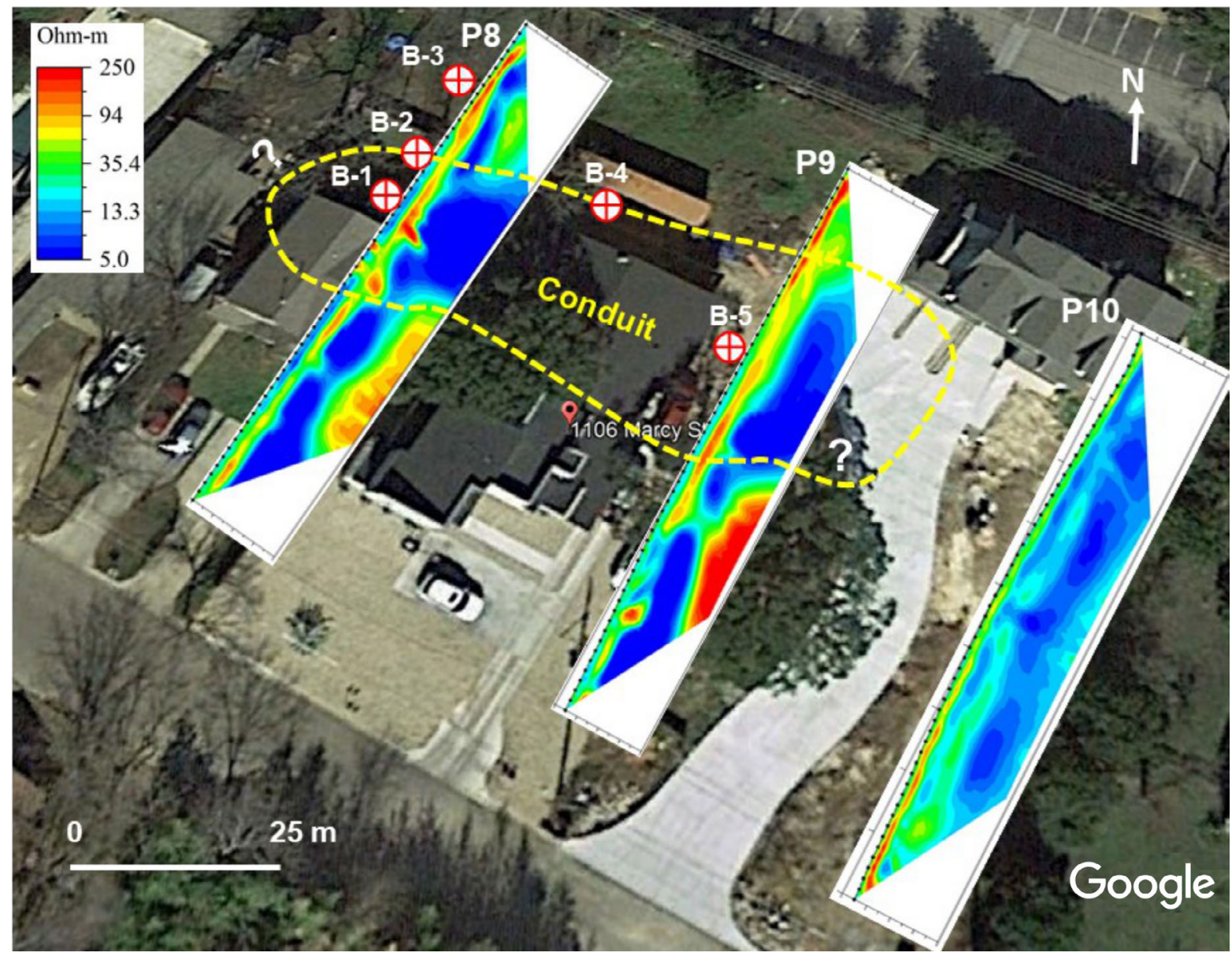

Figure 14: Resistivity profiles superimposed on a Google Map ${ }^{\mathrm{TM}}$ in the vicinity of the residential site. Note that the low resistivity anomaly is not observed on resistivity profile P10. White question marks indicate the possible extension of the conduit anomaly in the east and west directions. O2019 Google LLC, used with permission. Google and the Google logo are registered trademarks of Google LLC.

about $4 \mathrm{~m}$. This ash layer is less than a meter thick and is underlain by tuff deposit as thick as $10 \mathrm{~m}$. Borehole B-3 was terminated within the Austin Chalk. Borehole B-4 was drilled beneath the Austin Chalk and terminated within an ash layer underlying Austin Chalk. The depth to the top of the ash layer $(4 \mathrm{~m})$ is about the same depth as the B-1 and B- 2 boreholes. Identification and description of the borehole cuttings corresponded well with the resistivity data. Four of the borings indicated severely weathered tuff interbedded with suspected ash deposits located beneath Austin Chalk (Figure 16). 
Table 1: Stratigraphic relationship between formations of the Austin Group (modified from Young and Woodruff [1985]). Underlying and overlying the Austin Group are Eagle Ford and Taylor formations, respectively.

\begin{tabular}{|c|c|c|}
\hline Formation & Description & $\begin{array}{l}\text { Thickness in the } \\
\text { Austin area }(\mathrm{m})\end{array}$ \\
\hline Sprinkle & $\begin{array}{l}\text { Massive, calcareous } \\
\text { claystone }\end{array}$ & 100 \\
\hline Pflugerville & $\begin{array}{l}\text { Marly and chalky } \\
\text { limestone }\end{array}$ & 22 \\
\hline Burditt & $\begin{array}{l}\text { The Burditt Marl } \\
\text { is a soft, clayey } \\
\text { limestone }\end{array}$ & 5 \\
\hline Dessau & $\begin{array}{l}\text { Chalky limestone. It } \\
\text { is dominantly a } \\
\text { sparse to fairly dense } \\
\text { limestone }\end{array}$ & $25-30$ \\
\hline Jonah & $\begin{array}{l}\text { Thick beds of } \\
\text { limestone; it is less } \\
\text { chalky than Vinson }\end{array}$ & 8 \\
\hline $\begin{array}{l}\text { Vinson } \\
\text { Chalk }\end{array}$ & $\begin{array}{l}\text { Chalky limestone; } \\
\text { contains soft and } \\
\text { hard chalk; bottom } \\
\text { contact with Atco } \\
\text { is gradual }\end{array}$ & 30 \\
\hline Atco & $\begin{array}{l}\text { Alternating beds } \\
\text { of massive lime- } \\
\text { stone with more } \\
\text { fissile limestone; } \\
\text { it contains much } \\
\text { less chalk than } \\
\text { Vinson Chalk }\end{array}$ & $15-20$ \\
\hline
\end{tabular}

\section{Discussion}

Small-volume shallow marine volcanism is relatively common on Earth, but relatively poorly resolved due to the logistical and technical difficulty in studying these features in subaqueous environments [Kano 1998; Kokelaar and Busby 1992; Mueller 2001; Schneider 2000]. The BMP offers an excellent opportunity to perform high-resolution geophysical investigations of shallow marine vents that are exposed and eroded. Nevertheless, the study of these features is hampered because Austin is a rapidly developing urban area. Here, electrical resistivity and magnetic surveys were designed around anthropogenic features (houses, railroad tracks) to optimize resolution. While limited to the shallow subsurface (up to $35 \mathrm{~m}$ in this case) the methods provide a

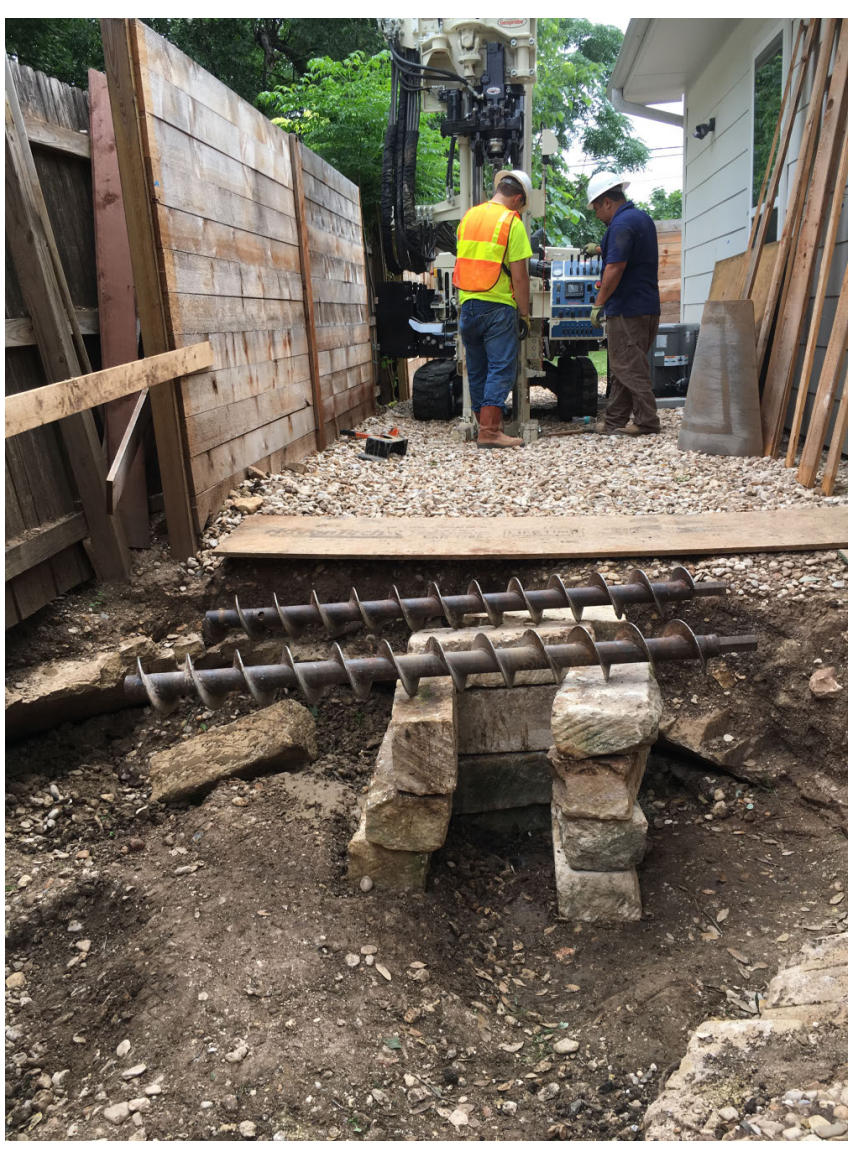

Figure 15: Picture showing the location of the cistern (old water well) and drilling at borehole location B-1. Resistivity profile P8 was surveyed along the corridor between the wooden fence and the house.

much clearer perspective on the near vent volcanic features than is otherwise possible. These techniques may work well in a variety of volcanic fields in urban areas, such as Mexico City and Auckland [Siebe and Macías 2006; Lindsay et al. 2011].

The critical feature revealed by the resistivity results from St. Elmo railroad cut site is that high resistivity limestone blocks or clusters of blocks are located in zones within the vent complex that are otherwise characterized by low resistivity. This interpretation is founded on the results of Williamson Creek volcanic mound, which is located about $2 \mathrm{~km}$ to the south of St. Elmo site [Saribudak 2016]. At the Williamson Creek site, scattered high resistivity blocks were also observed on resistivity profiles. Some of these limestone blocks out-crops within the volcanic mound. In addition, there have been also numerous similar observations made over oil fields containing inclusions of fragments of Austin Chalk or older rocks within the volcanic eruption centers [Collingwood and Rettger 1926; Simmons 1967; Matthews 1986].

These isolated high resistivity zones are more common near the edges of the vent complex. Some resistivity profile lines (e.g. P3 and P10) are relatively free of high resistivity zones. Furthermore, in the near-vent 


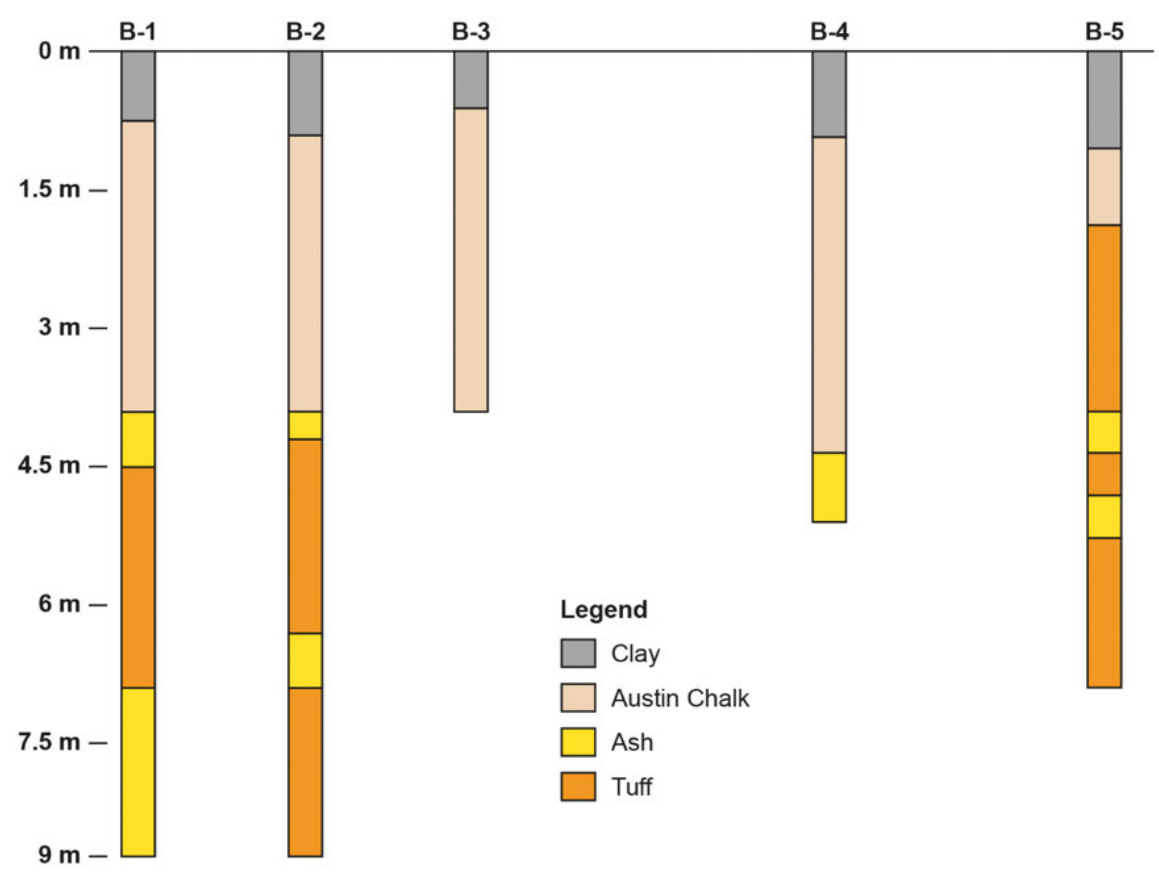

Figure 16: Correlation of data from five boreholes. Note that all boreholes are shown aligned; however, boreholes B-4 and B-5 are actually located to the southeast of boreholes B-1, B-2 and B-3 (see Figure 14).

facies, two low resistivity zones can be distinguished (roughly $15 \Omega \mathrm{m}$ and roughly $6 \Omega \mathrm{m}$ ). This variation in resistivity may be related to variations within conduits and near-vent deposits. Slightly higher resistivity is expected in near-vent facies enriched with limestone lithic fragments, whereas the lowest resistivities are expected in zones of relatively clean and limestone-free conduit. Finally, the boreholes and limited outcrop data show that the moderately low resistivity zones correspond to altered volcaniclastic rocks commonly occurring in near-vent facies in distributed volcanic fields-in this case, with limestone lithics. Thus, the geophysical surveys show that the conduits retain structure, with predominantly central areas of uniformly low resistivity, and marginal areas of rapid variation in resistivity, with low resistivity zones.

Comparing the scale and form of the inverted resistivity anomalies with geologic data from other regions suggests that these tuff mounds of the BMP are largely near-vent facies developed in the shallowest parts of diatremes through reworking of juvenile material (palagonitized basalt) and lithic material (brecciated Austin Chalk) during short-lived explosive subaqueous eruptions. Geologic investigations of shallow diatremes have shown that they most frequently have complex structure, with zones of predominantly brecciated host rock (in this case Austin Chalk), zones of intense mixing and reworking of pyroclastic and lithic material, predominantly but not exclusively at the margins of the conduit, and some zones of predominantly juvenile material (in this case basalt) [White 1991; Hooten and Ort 2002; Le- febvre et al. 2013; White and Ross 2011]. These features are commonly associated with vent complexes in distributed volcanic fields [Kiyosugi et al. 2012; Richardson et al. 2015].

Resistivity results from the residential site, not far from the St. Elmo volcanic mound, indicate a conduit which is similar to the conduit anomalies observed on the St. Elmo railroad cut site. Borehole data obtained from tuff deposits within the conduit anomaly display multiple ash layers.

\section{Conclusions}

Results from three resistivity profiles are interpreted as subsurface evidence that the St. Elmo submarinemound has high resistivity limestone blocks scattered randomly within the resistivity sections as deep as 35 $\mathrm{m}$. The distribution of these chaotic limestone blocks is more evident on the eastern resistivity profiles than the western resistivity profiles. These limestone blocks are interpreted to be erratic blocks of Austin Chalk, which were probably torn from the walls of the volcanic vent and ejected. Resistivity data from eastern profiles indicate three conduit-like anomalies, and are probably part of the eruption center in the study area. Magnetic data along one profile correlates well with the location of contact between the mound and the limestone unit. Magnetic data along two other profiles show a high magnetic anomaly that correlate with the approximate location of an inferred conduit. These high 
magnetic anomalies correlate well with the resistivity anomalies, strengthening the interpretation of the resistivity data.

Results of this study and others [Saribudak and Caran 2015; Saribudak 2016] showcase the effectiveness of integrated resistivity and magnetic imaging for mapping and characterizing volcanic mounds in detail, as well as constraining the lateral and vertical boundaries of volcanic mounds, and in this case, the adjacent Austin Chalk formation. These results also indicate that the combination of resistivity and magnetic data may provide valuable information in terms of delineating volcanic vents and dikes and defining the geological contacts of volcanic rocks in the Austin area and in the state of Texas. Additional resistivity surveys, in conjunction with magnetic surveys, could also offer useful information on the structure of volcanic plugs, which are potential oil and gas traps in the state of Texas. The procedures developed here may have applications in other areas with comparable geological conditions.

\section{ACKnowledgements}

I am grateful to Chuck Connor for his detailed and careful review of the manuscript. His help greatly improved the content of the manuscript and linked this study to similar international studies. Reviews by Stephanie Barde-Cabusson and Lis Gallant have considerably improved the manuscript, and for that I am thankful to them. I thank Chris Caran for introducing the site, and Al Cherepon for kindly granting permission to use his field pictures. The late Todd Housh must also be greatly acknowledged for his work on the geology of the St. Elmo railroad cut, which was presented in the Austin Geological Society Guidebook (2006). I am thankful to Jack Sharp and Robert Reed for their help during for the thin sections. Special thanks go to Alf Hawkins for his help during the field campaign. Lastly, but not least, I thank Cally Martin for her permission to publish the resistivity data from her residential place.

\section{Data AVAilability}

Data can be made available on request.

\section{Copyright NOTICE}

C The Author(s) 2019. This article is distributed under the terms of the Creative Commons Attribution 4.0 International License, which permits unrestricted use, distribution, and reproduction in any medium, provided you give appropriate credit to the original author(s) and the source, provide a link to the Creative Commons license, and indicate if changes were made.

\section{REFERENCES}

Barde-Cabusson, S., X. Bolós, D. Pedrazzi, R. Lovera, G. Serra, J. Mart1, and A. Casas (2013). "Electrical resistivity tomography revealing the internal structure of monogenetic volcanoes". Geophysical Research Letters 40.11, pp. 2544-2549. DoI: 10.1002/grl.50538.

Blaikie, T., L. Ailleres, P. Betts, and R. Cas (2014). "A geophysical comparison of the diatremes of simple and complex maar volcanoes, Newer Volcanics Province, south-eastern Australia". Journal of Volcanology and Geothermal Research 276, pp. 64-81. DoI: $10.1016 /$ j . jvolgeores.2014.03.001.

Bruno, P. P. G., G. P. Ricciardi, Z. Petrillo, V. D. Fiore, A. Troiano, and G. Chiodini (2007). "Geophysical and hydrogeological experiments from a shallow hydrothermal system at Solfatara Volcano, Campi Flegrei, Italy: Response to caldera unrest". Journal of Geophysical Research 112.B6. Dor: 10.1029/2006 jb004383.

Capital Geotechnical Services, PLLC (2017). Geotechnical Evaluation and Forensic Assistance, Distressed Duplex at 1106 Marcy Street, Austin, Texas. Tech. rep. \#170174. Capital Geotechnical Services, PLLC.

Caran, C., T. Housh, and A. Cherepon (2012). "Volcanic features of the Austin area". Texas, Austin Geological Society Field Trip Guidebook 26.

Collingwood, D. M. (1930). "Magnetics and Geology of Yoast Field, Bastrop County, Texas". AAPG Bulletin 14, pp. 1192-1197. Dor: 10 . 1306 / 3d932922 - 16b1 11d7-8645000102c1865d.

Collingwood, D. M. and R. E. Rettger (1926). "The Lytton Springs Oil Field, Caldwell County, Texas". AAPG Bulletin 10, pp. 953-975. Dor: 10 . $1306 /$ 3d93274a-16b1-11d7-8645000102c1865d.

Courtland, L. M., S. E. Kruse, C. B. Connor, L. J. Connor, I. P. Savov, and K. T. Martin (2012). "GPR investigation of tephra fallout, Cerro Negro volcano, Nicaragua: a method for constraining parameters used in tephra sedimentation models". Bulletin of Volcanology 74.6, pp. 1409-1424. Dor: 10 . 1007 / s00445012-0603-3.

Dahlin, T. and M. Loke (1998). "Resolution of 2D Wenner resistivity imaging as assessed by numerical modelling". Journal of Applied Geophysics 38.4, pp. 237249. DoI: 10 . 1016/s0926-9851 (97)00030-x.

Di Giuseppe, M. G., A. Troiano, M. Di Vito, R. Somma, and F. Matano (2017). "Definition of small-scale volcanic structures by Electrical Resistivity Tomography: the Trentaremi cone, an example from the Campi Flegrei Caldera (Italy)." Annals of Geophysics 60.5. ISSN: 2037-416X. DoI: $10.4401 / \mathrm{ag}-7397$.

Di Giuseppe, M. G., A. Troiano, A. Fedele, T. Caputo, D. Patella, C. Troise, and G. De Natale (2015). "Electrical resistivity tomography imaging of the nearsurface structure of the Solfatara crater, Campi Flegrei (Naples, Italy)". Bulletin of Volcanology 77.4. Dor: 10. 1007/s00445-015-0910-6. 
EarthImager $^{\mathrm{TM}}$ (2014). EarthImager 2D Manual (20022014). Resistivity and IP Inversion Software. English. Version Version 2.4.2.

Ewing, T. E. and S. C. Caran (1982). "Late Cretaceous Volcanism in South and Central Texas-Stratigraphic, Structural, and Seismic Models". Transactions of the Gulf Coast Association of Geological Societies. Ed. by M. Malek-Aslani. Vol. 32.

George, O., J. McIlrath, A. Farrell, E. Gallant, S. Tavarez, A. Marshall, C. McNiff, M. Njoroge, J. Wilson, C. Connor, L. Connor, and S. Kruse (2015). "HighResolution Ground-Based Magnetic Survey of a Buried Volcano: Anomaly B, Amargosa Desert, NV". Statistics in Volcanology 1, pp. 1-23. DoI: 10.5038 / 2163-338x.1.3.

Griffin, R., T. Ewing, S. Bergman, and M. Leybourne (2005). Volcanic Rocks of the Balcones Igneous Province: Field Trip Guidebook. University of Texas at Dallas.

Griffiths, D. and R. Barker (1993). "Two-dimensional resistivity imaging and modelling in areas of complex geology". Journal of Applied Geophysics 29.3-4, pp. 211-226. Dor: 10 . 1016/0926-9851 (93) 90005-j.

Hermans, T., F. Nguyen, T. Robert, and A. Revil (2014). "Geophysical Methods for Monitoring Temperature Changes in Shallow Low Enthalpy Geothermal Systems". Energies 7.8, pp. 5083-5118. Dor: $10.3390 /$ en7085083.

Hooten, J. and M. Ort (2002). "Peperite as a record of early-stage phreatomagmatic fragmentation processes: an example from the Hopi Buttes volcanic field, Navajo Nation, Arizona, USA". Journal of Volcanology and Geothermal Research 114.1-2, pp. 95-106. Dor: 10. 1016/s0377-0273(01)00282-7.

Kano, K. (1998). "A shallow-marine alkali-basalt tuff cone in the Middle Miocene Jinzai Formation, Izumo, SW Japan". Journal of Volcanology and Geothermal Research 87.1-4, pp. 173-191. DOI: 10 . 1016 / s0377 0273 ( 98 ) 00098-5.

Kiyosugi, K., C. B. Connor, P. H. Wetmore, B. P. Ferwerda, A. M. Germa, L. J. Connor, and A. R. Hintz (2012). "Relationship between dike and volcanic conduit distribution in a highly eroded monogenetic volcanic field: San Rafael, Utah, USA". Geology 40.8, pp. 695-698. DoI: 10.1130/g33074.1.

Kokelaar, P. and C. Busby (1992). "Subaqueous Explosive Eruption and Welding of Pyroclastic Deposits". Science 257.5067, pp. 196-201. Dor: 10.1126 / science.257.5067.196.

Lefebvre, N. S., J. D. L. White, and B. A. Kjarsgaard (2013). "Unbedded diatreme deposits reveal maar-diatreme-forming eruptive processes: Standing Rocks West, Hopi Buttes, Navajo Nation, USA". Bulletin of Volcanology 75.8. Dor: 10 . 1007 / s00445-0130739-9.

Lindsay, J., G. Leonard, E. Smid, and B. Hayward (2011). "Age of the Auckland Volcanic Field: a review of existing data". New Zealand Journal of Geology and Geophysics 54.4, pp. 379-401. Dor: 10 . $1080 /$ 00288306.2011 .595805$.

Loke, M. (2000). Electrical imaging surveys for environmental and engineering studies, A practical guide to 2-D and 3-D surveys. Penang, Malaysia.

Marshall, A., C. Connor, S. Kruse, R. Malservisi, J. Richardson, L. Courtland, L. Connor, J. Wilson, and M. A. Karegar (2015). "Subsurface structure of a maar-diatreme and associated tuff ring from a highresolution geophysical survey, Rattlesnake Crater, Arizona". Journal of Volcanology and Geothermal Research 304, pp. 253-264. DoI: 10.1016/ j . jvolgeores . 2015.09.006.

Matthews, T. (1986). "The petroleum potential of "serpentine plugs" and associated rocks". Central and South Texas: Baylor Geological Studies: Bulletin 44.

Moon, C. (1942). "A study of the igneous rocks of Travis County". MA thesis. University of Texas at Austin, USA.

Mueller, W. (2001). "Subaqueous eruption-fed density currents from small volume mafic eruptions: the crossover from volcanology to sedimentology". Commission on Volcanogenic Sediments (CVS) Newsletter 20, pp. 2-9.

Ormond, J. C. (1984). "Emprical magnetic modeling of Cretaceous submarine volcanic mounds in south Texas". MA thesis. Texas Tech University, USA.

Read, D. (2017). Foundation Performance Evaluation, Preliminary Report. Tech. rep. \#1719000030.001. MLAW Forensic, Inc, 1106 Marcy Street, Austin, Texas.

Richardson, J., C. Connor, P. Wetmore, L. Connor, and E. Gallant (2015). "Role of sills in the development of volcanic fields: Insights from lidar mapping surveys of the San Rafael Swell, Utah". Geology 43.11, pp. 1023-1026. Dor: 10.1130/g37094.1.

Romberg, F. and V. E. Barnes (1954). “A geological and geophysical study of Pilot Knob (South), Travis County, Texas". Geophysics 19.3, pp. 438-454. DoI: 10 . $1190 / 1.1438016$.

Rucker, D. F. and D. R. Glaser (2015). "Standard, Random and Optimum Array Conversions from Twopole Resistance Data". Journal of Environmental \& Engineering Geophysics 20.3, pp. 207-217. DoI: 10 . 2113 / jeeg20.3.207.

Saribudak, M. (2016). "Near-surface geophysical mapping of an Upper Cretaceous submarine volcanic vent in Austin, Texas, USA". The Leading Edge 35.11, pp. 986-994. DoI: 10.1190/tle35110986.1.

Saribudak, M. and C. Caran (2015). "Resistivity, magnetic data delineate volcanic tuff in Travis County, Texas". Oil \& Gas Journal 113.10, pp. 52-57.

Schneider, J.-L. (2000). "Volcaniclastic sedimentation in submarine settings: products and processes". Volcaniclastic Rocks, from Magmas to Sediments. Ed. by H. Leyrit and C. Montenant, pp. 175-192. 
Shelby, T. H. (1934). "The geology of an area lying along Barton Creek Southwest of Austin, Texas". MA thesis. University of Texas at Austin, USA.

Siebe, C. and J. L. Macías (2006). "Volcanic hazards in the Mexico City metropolitan area from eruptions at Popocatépetl, Nevado de Toluca, and Jocotitlán stratovolcanoes and monogenetic scoria cones in the Sierra Chichinautzin Volcanic Field". Geological Society of America Special Papers 402, p. 253.

Simmons, K. A. (1967). “Around The Society: A Primer on "Serpentine Plugs" in South Texas". Bulletin of South Texas Geological Society 7.2, pp. 5-17.

Udden, J. A. and H. P. Bybee (1916). "The Thrall oil field". Bulletin of the University of Texas 66.

Valentine, G. A. and C. B. Connor (2015). "Basaltic Volcanic Fields". The Encyclopedia of Volcanoes. Ed. by H. Sigurdsson, B. Hougton, S. McNutt, H. Rymer, and J. Stix. Elsevier, pp. 423-439. DoI: 10 . 1016 / b978-0 12-385938-9.00023-7.

White, J. and P.-S. Ross (2011). "Maar-diatreme volcanoes: A review". Journal of Volcanology and Geother- mal Research 201.1-4, pp. 1-29. Dor: $10.1016 / \mathrm{j}$. jvolgeores.2011.01.010.

White, J. D. (1991). "Maar-diatreme phreatomagmatism at Hopi Buttes, Navajo Nation (Arizona), USA". Bulletin of Volcanology 53.4, pp. 239-258. DOI: 10 . 1007 / bf00414522.

Wilkinson, P. (2006). "Effects of a conductive rail on parallel apparent resistivity measurements". British Geological Survey Internal Report IR/06/096.

Xia, J., G. Ludvigson, R. D. Miller, L. Mayer, and A. Haj (2010). "Delineation of a volcanic ash body using electrical resistivity profiling". Journal of Geophysics and Engineering 7.3, pp. 267-276. DoI: 10 . $1088 /$ $1742-2132 / 7 / 3 / 005$.

Young, K., S. Caran, and T. Ewing (1982). "Cretaceous volcanism in the Austin area, Texas". Austin Geological Society Guidebook 4, p. 66.

Young, K. and C. Woodruff (1985). Austin chalk in its type area-stratigraphy and structure. Vol. 7. Austin Geological Society. 